\title{
PENGEMBANGAN LKS MATERI LISTRIK STATIS BERORIENTASI NILAI AL-QUR'AN UNTUK SISWA KELAS IX SEKOLAH MUHAMMADIYAH
}

\author{
Friska Cahyati \\ Nyoto Suseno \\ Pendidikan Fisika Universitas Muhammadiyah Metro \\ Email: nyotoseno@yahoo.co.id
}

\begin{abstract}
The objectives of this research and development was carried out to design a work-sheet of the static electricity material with Qur'an value and contant. Preliminary data is done in Muhammadiyah junior high schools of East Lampung. Steps of research and development include, potential and problems analyst, gather information, design, validation, and revisions to the product. The instruments used to collect data by documentation, literature studies, questionaire and observation sheets. Aspect validity work-sheet include: didaktif, construction and techniques. The results showed that developed work-sheet was very good category. The advantages work-sheet improve not only knowledge but olso spiritual attitude. Disadvanteges was moment classroom activity the students more interested to the Al-Qur'an words then the material physics content.
\end{abstract}

Keyword: development, worksheets, value of the Qur'an, static electricity material.

\section{PENDAHULUAN}

Ilmu alam tidak hanya bersumber dari teori para ahli dan konteks fenomena alam sekitar, alqur'an hendaknya dijadikan sebagai sumber belajar, dimana terdapat ayatayat Al-Qur'an yang menjelaskan prinsip dasar dari semua ilmu pengetahuan, baik mengenai bahasa arab, syari'at, filsafat dan akhlak, selain itu dapat mengarahkan siswa mempelajari fenomena maupun kejadian alam yang ada di lingkungan sekitar. Ayat yang mula-mula turun ialah berhubungan dengan perintah untuk mempelajari ilmu pengetahuan, yaitu Al-Alaq:1-5, dan Az-Zumar ayat 9. Menurut Zuhairini (1994: 33) ada bagian alam yang dengan mudah bisa dibudayakan, tetapi bagian lainnya 
Friska. C., Nyoto. S. - Pengembangan LKS Materi...

sulit untuk ditundukkan, bahkan didapati bagian alam yang membahayakan kehidupan manusia, usaha pembudayaan justru menimbulkan kehancuran yang mengancam kehidupan manusia.

Berdasarkan

ungkapan

tersebut, maka perlu satu acuan dalam pengembangan ilmu pengetahuan yang kebenarannya mutlak, yaitu ilmu pengetahuan yang berorientasi terhadap petunjuk dan kandungan AlQur'an. Menurut Baharuddin \& Wahyuni (2007: 37) dalam Al-Qur'an banyak sekali ayat yang memerintahkan manusia untuk selalu menggunakan akal dalam memahami dan merenungi segala ciptaan dan kebesaran Alloh di alam ini. Buku dan bahan ajar yang telah beradar dan digunakan di berbagai sekolah umumnya mengungkap teori berdasarkan pendekatan konseptual ataupun kontekstual, sedangkan untuk sekolah berbasis agama islam diperlukan suatu sajian bahan ajar yang mengkoneksikan atau bahkan berorientasi kandungan Al-Qur'an. Menurut Putra (2013:68) bahwa "Penelitian dan pengembangan adalah mencaritemukan pengetahuan baru dengan mengkreasi produk dan proses yang baru sebagai aplikasi pengetahuan". Dalam Al-Qur'an Allah SWT menganjurkan bagi setiap pendidik untuk selalu mencari jalan dan media terbaik agar memudahkan siswa untuk menerima ilmu Allah SWT, sebagaimana dalam Al-Qur'an secara prinsip disampaikan dalam surat Al-Maidah ayat 35.

Bahan ajar yang akan dikembangkan adalah Lembar Kerja Siswa (LKS) yang didefinisikan sebagai lembaran-lembaran berisi tugas yang harus dikerjakan oleh siswa. LKS ini berupa petunjuk dan langkah-langkah untuk menyelesaikan suatu tugas. Perlu diketahui bahwa petunjuk dan tugas yang dimaksud bukan berupa perintah mengerjakan soal essay dan pilihan ganda. Melainkan, langkah-langkah yang menuntun siswa dalam memahami ilmu pengetahuan melalui berbagai sajian dan langkah kegiatan sesuai dengan tujuan yang akan dicapai, termasuk kutipan ayat dari kandungan Al-Qur'an untuk dikaitkan dengan sajian materi yang mudah dipelajari siswa. Salah satu keuntungan penggunaan LKS selain sebagai 
Friska. C., Nyoto. S. - Pengembangan LKS Materi...

panduan untuk mengarahkan siswa dalam belajar, menurut Butler \& Mc.Munn (2006: 125) LKS juga dapat digunakan untuk menganalisis dan mengukur seberapa jauh pemahaman yang telah dikuasai oleh siswa.

Salah satu dari tujuan pendidikan adalah pembentukan karakter siswa. Muslich (2006:84) mengatakan karakter merupakan nilainilai perilaku manusia yang berhubungan dengan Tuhan Yang Maha Esa, diri sendiri, sesama manusia, lingkungan, dan kebangsaan yang terwujud dalam pikiran, sikap, perasaan, perkataan, dan perbuatan.

Bahan ajar yang akan dikembangkan dalam penelitian pengembangan ini adalah LKS yang kajian materinya berorientasi dan bersumber dari kandungan dan nilainilai Al-Qur'an untuk sekolah berbasis Islam, khususnya sekolah Muhammadiyah, sehingga diharapkan pemahaman ilmu pengetahuan alam dan penerapan siswa bersuber dari AlQur'an.

\section{METODE}

Prosedur yang digunakan dalam penelitian ini yaitu merujuk pada langkah-langkah penelitian dan pengembangan menurut Sugiyono (2013: 298) yang ditunjukkan pada gambar berikut:

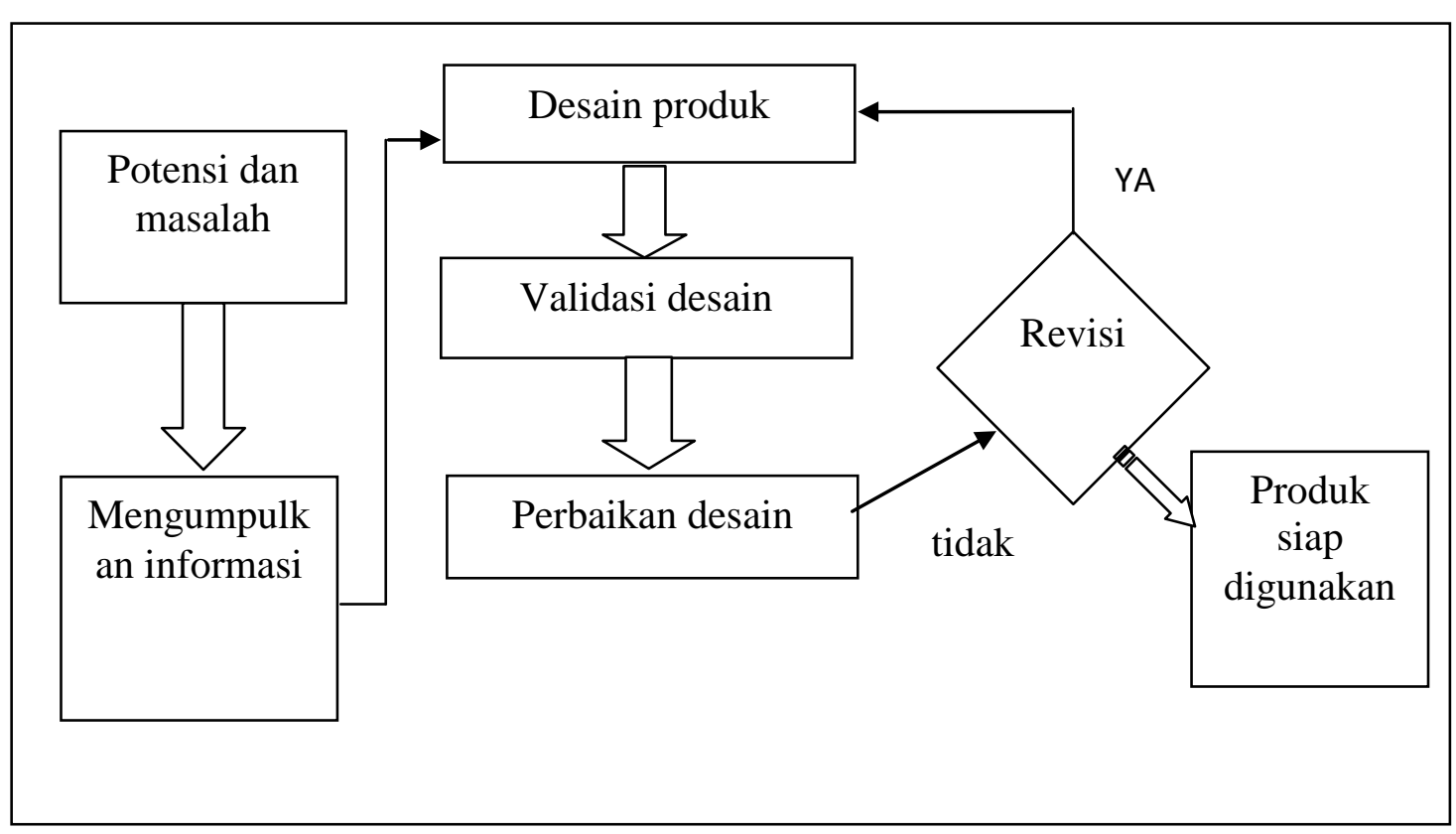

Gambar 1. Langkah-langkah Penelitian dan Pengembangan 
Friska. C., Nyoto. S. - Pengembangan LKS Materi...

\section{HASIL DAN PEMBAHASAN}

\section{Hasil Penelitian}

\section{- Studi Pendahuluan}

\section{a. Studi Lapangan}

Hasil Studi pendahuluan menunjukkan bahwa LKS yang sudah digunakan di Sekolahsekolah hanya sebatas mengungkap uraian materi, kegiatan dan soal-soal latihan. LKS yang telah digunakan di sekolah belum ada yang mengkoneksikan materi ilmu pengetahuan alam dengan nilainilai atau kandungan Al-Qur'an. Belum ada bahan ajar yang menggunakan Al-Qur'an sebagai sumber utama dalam mempelajarai ilmu pengetahuan. Sebagian sekolah telah menerapkan kurikulum 2013, dan sebagian yang lain menggunakan Kurikulum Tingkat Satuan Pendidikan (KTSP).

\section{b. Studi Literatur}

Dalam kurikulum 2013 salah satu kompetensi intinya adalah sikap spiritual, dimana bagi siswa yang beragama islam harus mampu mengaitkan materi

pelajarannya dengan sikap spiritualnya. Dengan demikian, maka untuk pendidikan yang berbasis islam seperti sekolah muhammadiyah perlu dikembangkan bahan ajar yang bersumber pada nilai atau kandungan Al-Qur'an.

LKS yang dikembangkan pada penelitian ini adalah pada materi listrik statis untuk mata pelajaran IPA SMP kelas IX. Berdasarkan kajian kurikulum dan ayat-ayat Al-Qur'an dapat dikemukakan kompetensi yang akan dikembangkan dalam pelajaran IPA kelas IX, materi listrik statis serta ayat-ayat AlQuran yang terkait terdapat pada tabel 1 .

\section{- Desain LKS}

Desain LKS berorientasi AlQur'an yang dikembangkan meliputi bagian-bagian sebagai berikut: (1) Halaman judul; (2) Standar isi kurikulum 2013; (3) Uraian materi listrik statis (meliputi: Listrik statis dalam kajian Al-Qur'an, Tujuan pembelajaran, Listrik statis dalam 
Friska. C., Nyoto. S. - Pengembangan LKS Materi...

surat Ar-Rad ayat 12, Nilai karakter

dalam ayat yang menjelaskan); (4)

Jendela informasi kita (meliputi:

Tujuan pembelajaran, Sejarah listrik

statis, Nilai karakter dalam surat Al-

Baqarah ayat 33); (5) Ringkasan

materi listrik statis (meliputi: Tujuan

pembelajaran, Muatan listrik, Nilai

karakter dalam surat Al-Mulk ayat 3,

Cara menimbulkan benda bermuatan listrik, Nilai karakter dalam surat AlBaqarah ayat 282 dan surat Az-Zumar ayat 18, Medan listrik, Nilai karakter dalam surat Ar-Rahman ayat 3-4, Hukum coulumb, Induksi listrik, Potensial listrik, Kegiatan praktikum, Manfaat listrik statis, Bingkai informasi, Motivasi); (6) Soal evaluasi; (7) Daftar pustaka

Tabel 1. Kompetensi Inti dan Kompetensi Dasar Kelas IX dan Ayat-ayat AlQur'an yang Terkait

\begin{tabular}{|c|c|c|}
\hline KOMPETENSI INTI & KOMPETENSI DASAR & $\begin{array}{l}\text { AYAT AL-QUR'AN } \\
\text { YANG TERKAIT }\end{array}$ \\
\hline $\begin{array}{l}\text { 1. Menghargai dan menghayati } \\
\text { ajaran agama yang dianutnya }\end{array}$ & $\begin{array}{l}\text { Mengagumi keteraturan dan } \\
\text { kompleksitas ciptaan Tuhan } \\
\text { tentang aspek fisik dan } \\
\text { kimiawi, kehidupan dalam } \\
\text { ekosistem, dan peranan } \\
\text { manusia dalam lingkungan } \\
\text { serta mewujudkannya dalam } \\
\text { pengamalan ajaran agama yang } \\
\text { dianutnya. }\end{array}$ & \multirow{4}{*}{$\begin{array}{l}\text { 1) Surat Ali-Imran } \\
\text { ayat: } 190-191 \\
\text { 2) Surat Ar-Rad ayat } \\
12 \\
\text { 3) Surat Al-Baqarah } \\
\text { ayat } 33 \\
\text { 4) Surat Al-Mulk } \\
\text { ayat } 3 \\
\text { 5) surat Al-Baqarah } \\
\text { ayat } 282 \\
\text { 6) surat Az-Zumar } \\
\text { ayat } 18 \\
\text { 7) surat Ar-Rahman } \\
\text { ayat } 3-4\end{array}$} \\
\hline $\begin{array}{l}\text { 2. Menghargai dan menghayati } \\
\text { perilaku jujur, disiplin, tanggung } \\
\text { jawab, peduli (toleransi, gotong } \\
\text { royong), santun, percaya diri, } \\
\text { dalam berinteraksi secara efektif } \\
\text { dengan lingkungan sosial dan } \\
\text { alam dalam jangkauan pergaulan } \\
\text { dan keberadaannya }\end{array}$ & 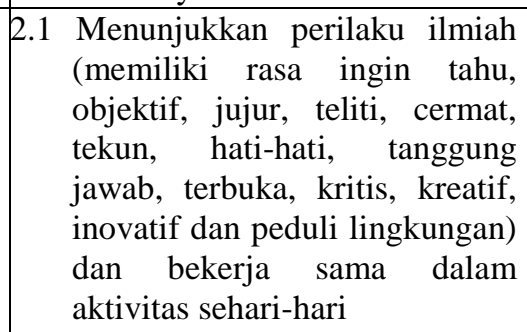 & \\
\hline $\begin{array}{l}\text { 3. Memahami dan menerapkan } \\
\text { pengetahuan } \\
\text { konseptual, dan prosedural) } \\
\text { berdasarkan rasa ingin tahunya } \\
\text { tentang ilmu pengetahuan, } \\
\text { teknologi, seni, budaya terkait } \\
\text { fenomena dan kejadian tampak } \\
\text { mata }\end{array}$ & $\begin{array}{l}\text { Mendeskripsikan atom dan } \\
\text { partikel penyusunnya, ion dan } \\
\text { molekul, serta hubungannya } \\
\text { dengan karakteristik } \\
\text { bahan/material yang digunakan } \\
\text { dalam kehidupan sehari-hari }\end{array}$ & \\
\hline $\begin{array}{l}\text { 4. Mengolah, menyaji dan menalar } \\
\text { dalam ranah } \\
\text { (menggunakan, }\end{array}$ & 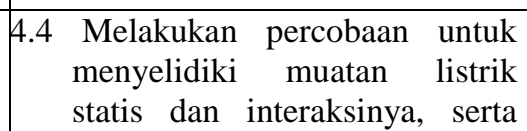 & \\
\hline
\end{tabular}


Friska. C., Nyoto. S. - Pengembangan LKS Materi...

merangkai, memodifikasi, dan membuat) dan ranah abstrak (menulis, membaca, menghitung, menggambar dan mengarang) sesuai dengan yang dipelajari di sekolah dan sumber lain yang sama dalam sudut pandang/teori

\section{- Hasil Validasi LKS}

Validasi terhadap produk LKS meliputi validasi aspek didaktif, aspek konstruksi dan aspek teknik. Hasil validasi menunjukkan bahwa LKS yang dikembangkan telah memenuhi syarat dedaktif dengan rata-rata 85,0 $\%$ termasuk dalam kategori sangat baik. Dari aspek konstruksi juga telah memenuhi syarat dengan rata-rata $81,3 \%$ dalam kategori sangat baik, dan aspek teknis dengan rata-rata $84,4 \%$ juga dalam kategori sangat baik. Secara umum LKS yang dikembangkan memiliki kategori sangat baik, dengan nilai rata-rata 83,6\%. Hasil validasi dapat diungkapkan dengan diagram berikut:

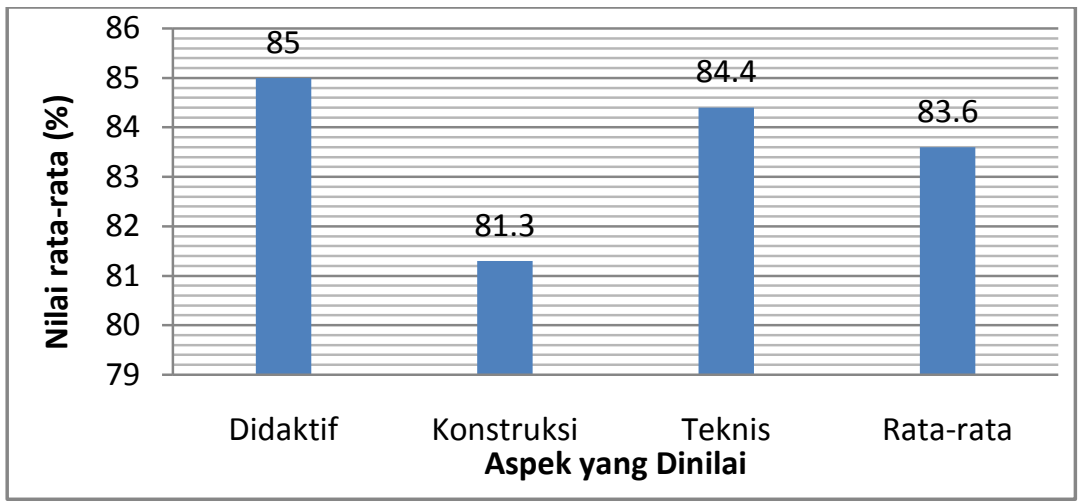

Gambar 2. Diagram Rekapitulasi LKS

Hasil uji coba lapangan dalam dengan kategori sangat layak. Dengan penggunaan LKS berorientasi nilai dan demikian, maka LKS berorientasi nilai kandungan Al-Qur'an di kelas dalam dan kandungan Al-Qur'an yang pembelajaran materi listrik statis, dikembangankan layak untuk menunjukkan bahwa respon siswa digunakan sebagai sumber belajar dalam penggunaan LKS tersebut pada materi listrik statis. memperoleh skor rata-rata $83,59 \%$, 
Friska. C., Nyoto. S. - Pengembangan LKS Materi...

- Keunggulan dan Kelemahan

\section{LKS yang Dikembangkan}

LKS beorientasi nilai dan kandungan Al-Qur'an ini disusun berdasarkan kurikulum 2013 yang bertujuan untuk mengajarkan materi fisika kepada siswa, sekaligus menanamkan nilai karakter berupa sikap spiritual yang bersumber dari Al-Qur'an. Hasil penilaian ahli dan uji lapangan menunjukkan bahwa LKS yang dikembangkan layak digunakan dalam katagori sangat baik. Namun demikian, LKS yang dikembangkan tentu memiliki kelebihan dan kelemahan. Kelebihan LKS berorientasi nilai dan kandungan $\mathrm{Al}-$ Qur'an yang telah dikembangkan dapat dikemukakan sebagai berikut:

a. Sajian LKS lebih mengarahkan siswa untuk mengembangkan sikap spiritual dalam mempelajarai materi listrik statis.

b. Soal-soal evaluasi disajikan pada setiap sub materi listrik statis sesuai dengan isi materi.

c. Membantu siswa dalam belajar memahami ayat Al-Qur'an yang disertai terjemahannya.

d. Sajian materi dilengkapi dengan gambar dan ilustrasi yang menarik dan sesuai dengan pembahasan materi.

e. LKS yang dikembangkan dapat membimbing siswa belajar mandiri dalam memahami pembahasan materi listrik statis.

Beberapa kelemahan LKS berorientasi nilai dan kandungan $\mathrm{Al}-$ Qur'an yang telah dikembangkan adalah sebagai berikut:

a. Banyak siswa yang memiliki kecenderungan untuk mempelajari ayat $\mathrm{Al}$-qur'an yang ada pada LKS dan kurang terfokus pada konten (materi ajar fisikanya), sehingga dalam penggunaan LKS berorientasi nilai dan kandungan Al-Qur'an, guru harus pandai mengarahkan ke focus materi kajian.

b. Siswa harus menambah waktu belajarnya di luar jam sekolah, karena keingintahuan siswa terkait nilai dan kandungan alQur'an yang diungkapkan dalam LKS memerlukan waktu dan pemahaman tersendiri.

c. Terdapat beberapa bagian ilistrasi yang gambarnya kurang jelas, sehingga mengganggu belajar siswa. 
Friska. C., Nyoto. S. - Pengembangan LKS Materi...

\section{PENUTUP}

\section{Kesimpulan}

Berdasarkan hasil dan penelitian terhadap LKS yan telah dikembangkan dapat disimpulkan sebagai berikut:

- Perkembangan LKS di sekolah saat ini belum ada yang menerapkan nilai dan kandungan Al-Qur'an, sebagai sumber belajar, sehingga perlu dilakukan pengembangan LKS berorientasi nilai dan kandungan Al-Qur'an.

- LKS berorientasi nilai dan kandungan Al-Qur'an yang telah dikembangkan layak digunakan dalam kategori sangat baik, namun demikian tentu produk yang dikembangkan tidak akan sempurna, sehingga memiliki kelebihan dan kekurangan.

- Kelebihan dari LKS berorientasi nilai dan kandungan Al-Qur'an yang telah dikembangkan antara lain: sajian LKS mengarahkan siswa untuk mengembangkan sikap spiritual dalam mempelajarai materi listrik statis; setiap sub materi listrik statis disertai dengan latihan dan evaluasi, membantu siswa dalam belajar Al-Qur'an yang disertai terjemahannya; sajian materi dilengkapi dengan gambar dan ilustrasi yang menarik; LKS yang dikembangkan dapat membimbing siswa belajar mandiri dalam memahami pembahasan materi listrik statis.

- Kelemahan LKS berorientasi nilai dan kandungan Al-Qur'an yang telah dikembangkan antara lain: banyak siswa yang memiliki kecenderungan untuk mempelajari ayat Al-qur'an yang ada pada LKS dan kurang terfokus pada konten (materi ajar fisikanya), sehingga dalam penggunaan LKS berorientasi nilai dan kandungan Al-Qur'an, guru harus pandai mengarahkan ke fokus materi kajian; siswa harus menambah waktu belajarnya di luar jam sekolah, terkait nilai dan kandungan al-Qur'an yang diungkapkan dalam LKS; terdapat beberapa bagian ilistrasi yang gambarnya kurang jelas, sehingga mengganggu belajar siswa. 
Friska. C., Nyoto. S. - Pengembangan LKS Materi...

\section{SARAN}

Berdasarkan hasil temuan dalam penelitian pengembangan ini, maka saran peneliti kepada pengguna maupun pembaca adalah sebagai berikut:

- Perlu dikembangkan LKS berorientasi nilai dan kandunga Al-Qur'an pada materi fisika yang lain, guna memperluas hasil yang telah dicapai dari penelitian ini.

- LKS berorientasi nilai dan kandungan Al-Qur'an yang telah dikembangkan, hendaknya digunakan oleh para guru di sekolah berbasis islam.

- Perlu dilakukan penelitian pengembangan bahan ajar lain yang berorientasi dan bersumber dari nilai dan kandungan AlQur'an.

\section{DAFTAR PUSTAKA}

Baharuddin \& Wahyuni, E. N. 2007. Teori Belajar dan Pembelajaran. Jogjakarta: ArRuzz Media.

Butler, S. M. \& Mc.Munn, N. D. 2006. A Teacher's Guide to Classroom Assessment. San Francisco: John Wiley \& Sons, Inc.
Departemen Agama.RI. 1989. $\underline{A l-}$ Qur'an dan Terjemahnya. Semarang: CV Alwaah

Muslich, Masnur. 2011. Pendidikan Karakter, menjawab tantangan krisis multidimensi. Jakarta: Bumi Aksara.

Putra, Nusa. 2013. Research Development Penelitian dan Pengembangan: Suatu Pengantar. Jakarta: Rajawali Pers

Sugiyono. 2013. Metode Penelitian Kuantitatif, Kualitatif, dan $R \&$ $D$. Bandung: Alfabeta

Zuhairini, dkk. 2004. Filsafat Pendidikan Islam. Jakarta: Bumi Aksara bekerjasana dengan Departemen Agama. 